\title{
Part III: Ritual Actions in Different Areas of Confrontation
}

\section{Hostages in peace processes}

The purpose of this part of the book is to elucidate how the giving and taking of hostages can be understood within a ceremony (or several ceremonies). The analysis must in part be carried out as a reconstruction because the medieval writers sometimes saw the giving and taking of hostage as irrelevant during negotiations: there were more important events to describe, such as the conversion of heathens. At the same time it is important to understand the use of a hostage as a major or essential part of a wider context: the peace process. The central parts of ceremonies are also analysed in this part, the treatment of the hostages, and how they were valued as persons. These ceremonial patterns may have taken altering expressions - regulations, and procedures - in different areas of confrontation and must therefore be understood by identifying their contextual factors. Initially Anglo-Saxon areas of confrontation are described and analysed, as well as some other contexts. In particular, it is emphasized that there were specific conditions for each individual conflict, with a subsequent peace, where personal interests may have been decisive for the outcome as well as other social mechanisms related to competitive groupings. Additional examples will also be taken from other confrontational areas involving Scandinavians: the Carolingian Empire, Denmark, and Norway.

How to cite this book chapter:

Olsson, S. 20r9. Ritual Actions in Different Areas of Confrontation. In: Olsson, S. The Hostages of Northmen: From the Viking Age to the Middle Ages. Pp. 8I-I 23. Stockholm: Stockholm University Press. DOI: https://doi. org/IO.I 6993/bba.c License: CC-BY. 


\section{Confrontations, peaces and hostages in the Anglo-Saxon confrontation areas}

The chronicler Asser (Ch. 47) reports how King Ceolwulf II of Mercia gave hostages to Vikings in $874 .{ }^{\mathrm{I}}$ According to the AngloSaxon Chronicle (874), The Great Heathen Army (OE mycel heathen here) had come from the kingdom of Lindsey to Repton in Mercia for winter quarters. They drove away Burgred, the king of Mercia, and all lands were subdued. That same year they granted Ceolwulf - a thegn (OE pegin) of the king - the rulership. Ceolwulf took an oath and gave hostages who would be at the Northmen's disposal any day they would need them. According to the Anglo-Saxon Chronicle, Ceolwulf would also be available for military service.

Obviously, the hostage appeared in this context in connection with the swearing of oaths. But in order to understand the ritual features of the hostage in this context, a historical survey is required. I have divided this overview in sequences year by year. I have deliberately limited the time span between the period 865 and 879 , and only dwelt on conflicts - and events that involved hostages - between kingdoms in the Heptarchy (the kingdoms of East Anglia, Essex, Kent, Northumberland, Mercia, and Wessex) and what is referred to in the chronicles as the 'Great Heathen Army'. Naturally, a discussion of the conflicts $787-896$ could also be subject to a broader discussion of the different opportunities for the conflicting sides to influence the outcome of the peace processes and the formation of societies (or state formation). In this context I refer to these limited time periods because they involve events with hostages.

865. The Great Heathen Army stops at Thanet in Kent, South East England. They make peace with the residents of Kent, who promise them money (debt) in exchange for peace. Despite the agreement, the Danes carry out raids in East Kent. In the same year, the Great Heathen Army goes into winter quarters in East Anglia. They are provided with horses by the residents and make peace with them.

866. This year, the Great Heathen Army goes into Northumbria and plunders York. There is an inner split among the Northumbrians who 
dispose their king and replace him with Ælla. The Northumbrians assemble an army that is beaten at York. The surviving Northumbrians make peace with the Danes.

867. The Great Heathen Army goes into winter quarters in Mercia in the current English Midlands. Mercia allies with Wessex.

869. The Great Heathen Army returns to York and stays there for a year.

870. The Great Heathen Army goes through Mercia to East Anglia. The ruler Edmund of East Anglia falls in battle with the Danes. The Danes raids the monastery of Petersborough. They go to winter quarters in Thetford.

87I. The Great Heathen Army enters Wessex and fights four battles against king Æthelred and his brother Alfred. The Great Heathen Army is divided into two parties. One party is led by the kings Bagsecg and Halfdan, the other by some earls. Both parties are beaten at Ashdown. Two weeks later, the Great Heathen Army defeats Alfred at Basing. Two months later, the Army triumphs over both Æthelred and Alfred at Merton. The same year comes a 'great summer fleet'. Æthelred passes away. Alfred takes over the throne and fights ten battles against the Army. An agreement is made.

872. The Great Heathen Army goes from Reading to London and sets winter quarters there. The Mercians make peace with the raiding army.

873. The Great Heathen Army enters Northumbria and sets winter quarters in Torksey at Lindsey. The Mercians re-launches the peace treaty with the Army.

874. The Great Heathen Army ranges from Lindsey to Repton. King Burhred is driven away. The Danes, instead, allow the deployment of one of Burhred's thegns as king. The new king must give oaths and a hostage, which is on stand-by for the Danes whenever they wish. The king, with his retinue, shall be ready for military service for The Great Heathen Army.

875. The Great Heathen Army ranges from Repton to Northumbria. Halfdan takes a part of the Army and ranges along the Tyne. The 
kings Guthrum, Oscytel, and Anund arrive in Cambridge with another part of the Army. Alfred wins a naval battle.

876. The Great Heathen Army retreats to Wareham, Dorset. King Alfred makes an agreement with the enemy fraction at Wareham. They swear before him on their holy ring that they will never return. They leave a hostage to Alfred. ${ }^{2}$ With the temporary peace treaty as protection, the Great Heathen Army descends towards Exeter in Devon during the night. That same year, Halfdan share lands in Northumbria and start working the soil.

877. A part of the Great Heathen Army retreats to Exeter, sets sails to the sea, and loses I 20 ships outside Swanage, Dorset, scattered in a mist. The second, mounted, part of the Army takes shelter from the pursuing Alfred in a fort. Then they give hostages to Alfred, as many as he wants, and swear 'grand' oaths. They maintain peace. Another part of the Army enters into Mercia, divides the country and gives a part of it to Ceolwulf.

878. During the Christmas month, a part of the Great Heathen Army enters Chippenham and invades Wessex. Alfred manages to flee. He builds a fortress (burh) in Athelney and musters an army. There is a battle at Edington where the Great Heathen Army is utterly destroyed. The rest of the army escapes to the fortress in Wareham. After two weeks, the Great Heathen Army surrenders. They give Alfred a prominent hostage; they give oaths, promise to leave Wessex, and their king (Guthrum) vows to take the baptism. Three weeks later, Guthrum comes to Aller, near Athelney, where Alfred receives him for baptism. At Wedmore his bound is removed. ${ }^{3}$ He stays twelve days at Altheney, and Alfred gives him many gifts. ${ }^{4}$

This division of events is not without contradictions because it is a matter of real events. Some years also overlap each other in different manuscript versions. The layout is primarily intended as an overview of the course of events and to clarify the actions that are essential for my reasoning. The division follows a timeline that largely corresponds to not only the scriptures of the Anglo-Saxon Chronicle but also with Asser's biography of Alfred. The political stages depicted in the division are crucial for understanding different ritual aspects of hostage exchanges, which we will turn to below. 


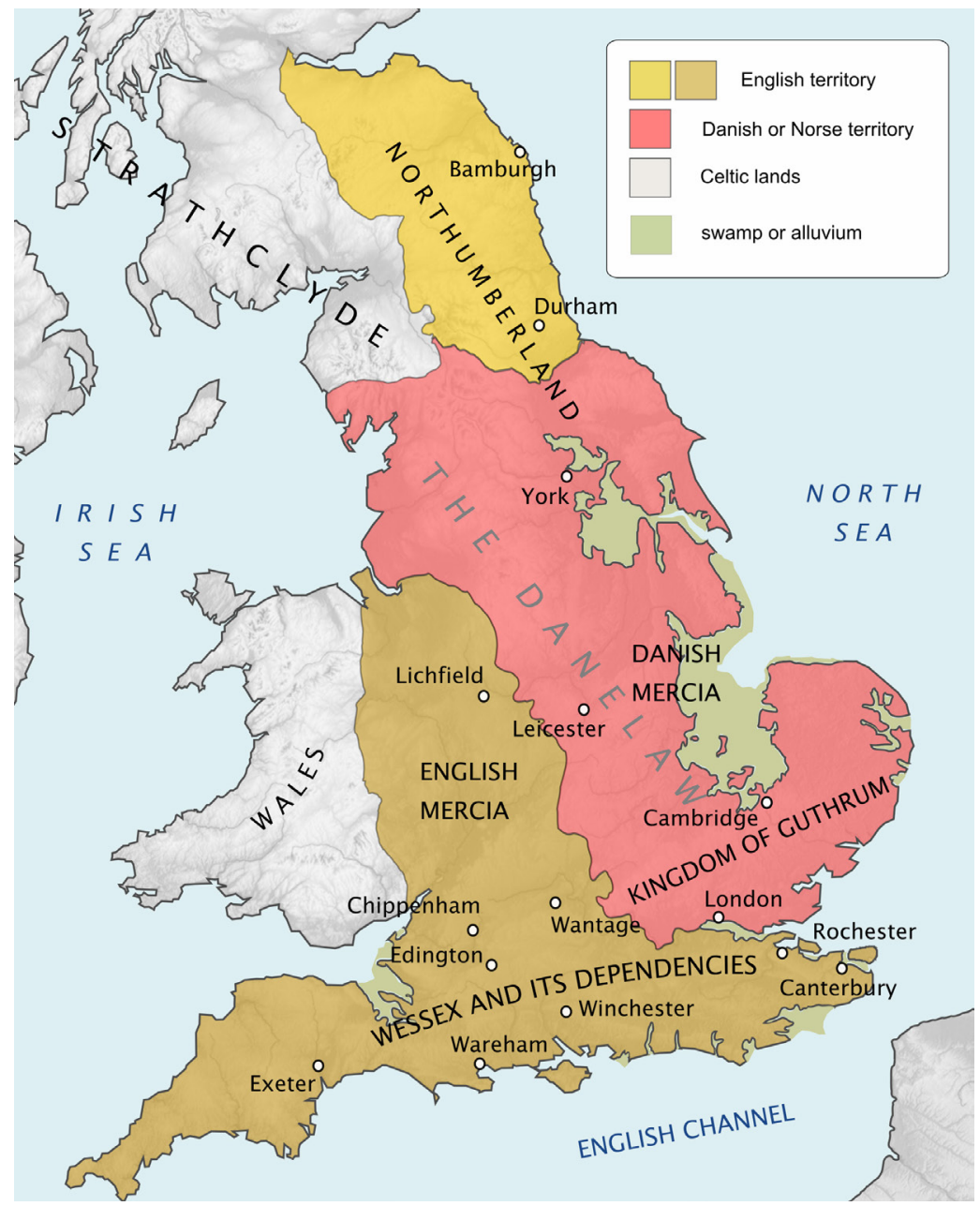

Figure III.1. Map of the realms of Wessex and Guthrum. Source: Wikipedia, Attribution-ShareAlike 3.0 Unported (CC BY-SA 3.0) https://sv.wikipedia. org/wiki/Danelagen\#/media/Fil:England_878.svg (2019-06-20).

\section{Legal, religious, social and economic aspects of hostages and other ritual acts}

As pointed out in the Part I, the side with the strongest military force is usually the one who dictates the terms. In the introduction, it was also mentioned that this was not always evident for the real 
situation of the Danelaw, which was ruled by several great men and different fractions of the Great Heathen Army, as is evidenced by the above sequences. ${ }^{5}$ The so-called Great Heathen Army was divided and led by several leaders. The fact that they were ascribed with titles such as 'king' and 'earl' did not necessarily meant that they corresponded to the titles of the Anglo-Saxon nobility. This division of the Army made it inevitable that there were several bases of support for different Scandinavian great men, something that is important to remember when different types of negotiations occurred even if it was not wartime. Thus, the concept of the Great Heathen Army could be misleading since it was not a unit in practice but consisted of groupings led by various great men with different interests.

According to the above timeline, different impact attempts were made by both sides (the Danes and the Anglo-Saxons) to regulate their counterparty. This can be compared to Figure I. I in Part I, where some of the means used to affect the outcome of a peace or to regulate a threatening violence are listed: ceremonies, oaths, guest attendance, hostages, weddings, exchanges of gifts, trade, and peace agreements. Such an attempt took place in 865 in Thanet, Kent, when the residents were allowed to pay tribute in return for peace, but the debt did not provide enough protection for the eastern part of Kent. The tribute can be seen as a gift (see below), but it was not a matter of economic cooperation in accordance with step two of the model in the introduction. This event took place before tributes were put into system. ${ }^{6}$ A similar attempt was made when the residents of East Anglia gave horses to the Danes and thus made an agreement. An alliance was also a way of influencing or strengthening a position vis-à-vis counterparties. Both Anglo-Saxons and Danes tried to build separate alliances. In 867, Mercia allied itself with Wessex. The part of the Great Heathen Army that entered Mercia in 873 drove away king Burhred and installed Ceolwulf as ruler in 874 . In exchange, Ceolwulf had to support the Great Heathen Army with auxiliary troops, which may be understood as if Ceolwulf was involved in an alliance, although built on a subordinate relationship.

In 877, when the Great Heathen Army suffered some defeat, they divided the lands in Mercia and gave a share to Ceolwulf, 
that is, the Army wanted to make a bond with him, thus strengthening the alliance when they were under pressure from other parts of the Heptarchy such as Wessex (see Figure III.I). ${ }^{7}$

The hostage, who in any case was unilateral according to Kosto's definition, ${ }^{8}$ appears in the case of Ceolwulf to have been a way to get free passage for the Army. They could then continue their plundering in other parts of the Heptarchy. However, the purpose of the hostage was also probably to regulate Ceolwulf; as a third party, the hostages guaranteed that Ceolwulf would not unite with anyone else or turn against the Danes. ${ }^{9}$ These were the same tactics that were used by Continental Germanic rulers. The Danes appear to have been familiar with these manoeuvres. ${ }^{\text {Io }}$ A particular aspect of the hostage in this case was that it was available for the Great Heathen Army not once but on request. The procedure can be compared with Kosto's point of view that the hostage was distinguished from other forms of personal security, like prisoners of war, since they were not routinely distributed. ${ }^{\text {II }}$ Moreover, if the giving of hostages can be understood as ritual acts, it means that the procedure was repeated. This hostage form in which hostages stood in constant preparedness through a peace settlement has been overlooked by Kosto in his study on various forms of hostage exchanges. However, the giving of hostages occurs in different contexts as in the aforementioned agreement between Guthrum and Alfred and the hostages mentioned in the Elder Westrogothic law when the ruler Ragnvald Knaphövde rode into the province of Västergötland in the II3 0 s. ${ }^{\text {I2 }}$ Some place names could indicate a similar function of hostages. One could therefore categorize this form of hostage as a disposable hostage. At the same time, it should be noted that the purpose of this kind of hostage could differ, although free passage may have been a common purpose. ${ }^{13}$ This could be compared to how the historian David Hill describes the border between Mercia and Wales as dynamic, during an occasionally violent period, between 704 and 1066 where both sides tried to adjust the border, which also involved the English (Wessex) attempt to control Wales. In these contexts, hostages were also used: "the mechanism for the control may be seen through the hostages mentioned in the "Ordinance concerning the Dunsæte", 
and there clearly is some recognized person who will meet bona fide travellers at the frontiers'. ${ }^{\mathrm{I}}$

With the defeats of 876 and 877 against Alfred, the situation was the reversed for the Great Heathen Army. Suddenly they were the weaker party during the negotiations. During the following peace summit, the Army had to provide hostages and they participated in ritual acts as the giving of oaths with the promise to leave Wessex. The writer of the Anglo-Saxon Chronicle noted that Alfred took as many hostages as he could (swa fela swa he habban). ${ }^{15}$ In this case, the number of hostages may have been exaggerated. Lavelle thinks that this was the case because it was uncertain whether Alfred had the upper hand in $877 .{ }^{16}$ In 878 , however, the victory was real. ${ }^{17}$

The hostage giving of 876 may still be interpreted as linked to the promise of the Army to leave Wessex. Such a promise was probably something of a literary cliché in both Anglo-Saxon and Continental-Germanic literature. ${ }^{18}$ Nevertheless, in the AngloSaxon Chronicle, at least outwardly, the purpose of the hostage is stated: keeping the Danes outside of Wessex. In the other cases, in 877 and 878 , the hostages were rather a symbolic expression of submission. ${ }^{19}$ In 878 , the subordination is clear because it was a prominent hostage that was given with people belonging to the political elite of the society. The hostage taking also has a ritual aspect in this case. The giving of the hostage is described with the Old English formula gislas salde, 'gave hostages', ${ }^{20}$ which can be compared with Marcel Mauss's theory of the gift: it must have a value that surpasses the (earlier) gift of the recipient. One can also note the financial counterperformance of Alfred; he gave extensive gifts, including estates, to Guthrum and members of his retinue. ${ }^{21}$ The comparison with Mauss's theory of gifts demands a more comprehensive analysis and we shall return to this matter later in Part IV.

In 876 , the Danes swore an oath on the holy ring (belgan beage) during the peace conference. This ring was an indigenous cultural object of the Danes and could have been rejected as 'pagan' by the Anglo-Saxon. It is interesting that the Anglo-Saxon Chronicle depicts how the Danes and the Anglo-Saxons participated in a 
common ceremony that appears to have been formally respected by both sides. Perhaps it can be described as an acculturative moment. The fact that the cultural object was brought to the place of meeting could be an example of a place that served as a mobile, cultic place. ${ }^{22}$ In this case the place was respected by both sides by the giving of hostages as a sign of good will. And the agreement that was settled seems to have been regarded as legally binding, as in the case of the oath. ${ }^{23}$

Asser has another version of the swearing of oaths by the Danes in 876. According to him, the Danes gave as many hostages as Alfred demanded and the oath was sworn on all the relics the king regarded as 'the highest after God'. They swore not to return to the kingdom of Alfred (as raiders). Asser also adds that the Danes had not sworn such an oath to any other people before. ${ }^{24}$ It is difficult to evaluate these two contradicting sources. Nonetheless, it is interesting that the Welsh monk Asser considers the relics to be crucial and implicitly the powers they turned to, which is a recurring theme in chronicles describing conflicts between Christians and heathens. ${ }^{25}$ At the same time, the giving of hostages and the giving of oaths are not actions that the Anglo-Saxon Chronicle or Asser deny. ${ }^{26} \mathrm{~A}$ similar pattern regarding the giving and taking of hostages and oaths can be found in descriptions in other contexts and under different political conditions (see below). The Scandinavian holy ring in the one case and the Christian relics in the other exemplify the use of cultural objects in ritual acts in both Scandinavian heathen and Anglo-Saxon Christian contexts. Interestingly the Christian Anglo-Saxons accepted the oath by the heathen Danes. It is likewise interesting that the 'heathens' accepted oaths that were Christian in content. When Guthrum swore his faithfulness to Alfred in 878 , it is perceived by Lavelle as either a subordination, or a submission, where Guthrum became 'Alfred's man'. ${ }^{27}$

In my view, it is in the light of the symbolism of these submissions that the giving and taking of hostages and the swearing of oaths should be understood in this case. Which deity the Danes turned to was probably not so important - probably more important to the Anglo-Saxons - because the Christian god was perceived as a god among others for the polytheistic Scandinavians. 
But even in a warlike situation, pragmatic reasons may have played a significant role. The Scandinavians faced a situation in which parts of the Great Heathen Army began to use the land in the conquered areas (e.g. 876 and 877), and this may have contributed to a standstill and a period of peace. That is not to state that this was a straightforward development, or that the will for peace would have been entirely intentional; on the contrary, the plundering continued for a while. ${ }^{28}$ But what I refer to as a 'regulation' - the ability to utilize the resources offered to achieve as favourable results as possible within the area of confrontation emerged. Here the actual performativeness of the ritual acts can be considered; both sides were given the opportunity to demonstrate their dependence on (or association with) their own traditions while establishing their adaptation to the new political situation.

During the ceremony - or ceremonies - in connection with the giving and taking of hostages between the Anglo-Saxons and the Danes, several ritual acts were performed:

(I) The giving and taking of hostages.

(2) Swearing of oaths at sacred objects.

(3) Baptism.

(4) The giving of gifts.

Probably - although this is not mentioned in the sources - joint festivities were held. During these celebrations, most likely toasts were made, a tradition that the Scandinavians could recognize from Scandinavia. In addition, a hunt could have occurred during these events. Lavelle has analysed various royal estates in Wessex in his doctoral dissertation. ${ }^{29}$ Some rulers in Wessex seem to have had several hunting cottages. At the same time, Lavelle points out that the evidence of royal hunting is less evident in the time before the conquest (in I066)..$^{\circ}$

There were several advantages with a hunt. According to Lavelle it had a symbolic, as well as psychosocial, function in which the hunt could be a form of 'controlled aggression' that broke the boredom of negotiations. ${ }^{31}$ As a power manifestation, the hunt may also have impressed the subjects and made the ruler appear vigorous before the comprehensive retinue and the dignitaries. 
Asser (Ch. 22), for example, praises the hunting skills of Alfred: 'he strives [...] in every branch of hunting [...] for no one else could approach him in skill and success in that activity, just as in all other gifts of God'. According to a local tradition, King Alfred's hunting lodge was in the market town of Chippenham, Wiltshire. ${ }^{32}$ In such cases, it is possible that it was used in some of the negotiations between the Danes and the Anglo-Saxons, although this is something we only can speculate about.

\section{The confirmation of Olaf Tryggvason}

The depiction of the giving of hostages in Southampton in 994 is one of the most interesting in the early medieval sources, as it describes how a Scandinavian ruler could participate in ceremonies where power strategies were displayed. The Anglo-Saxon Chronicle, which can be regarded as a primary source, describes several ritual acts in connection with a hostage giving. The description involves the kings Sweyn Forkbeard (ON Sveinn Tjúguskegg, OE Swegen) from Denmark and Olaf Tryggvason (OE Anelaf) from Norway. When the giving of hostages at Southampton was completed, the political situation was different compared to seven years earlier when both Sweyn and Olaf conducted small-scale raids. Both rulers had ambitions of their own: Olaf aspired to become ruler over Norway, and Sweyn wished to appear as a ruler of the same character as the Christian Anglo-Saxon kings. Initially, the purpose was to collect tributes, the so-called Danegeld. ${ }^{33}$ But with larger armies, Sweyn conquered England, while Olaf achieved his goal of becoming king of Norway - but only for a while. He fell at the battle of Svolder in the year ıooo.

In 994, Sweyn and Olaf attacked London. According to the Anglo-Saxon Chronicle, the Londoners offered hard resistance. Then the Scandinavians raided the rural areas of Essex, Kent, Sussex, and Hampshire instead. A tribute was offered to the staggering sum of 16,000 pounds by the Anglo-Saxons. ${ }^{34}$

Olaf and Sweyn went to winter quarters in Southampton and the tribute of London was sent to them. Then Æthelred II, king of Wessex, sent bishop Ælfeach and the ealdorman Æthelweard to retrieve Olaf. The Anglo-Saxons also sent hostages to the ships 
of the Scandinavians. The bishop and the ealdorman brought Olaf to Andover, where he was received and led to the king who bestowed him with royal gifts. Olaf made the promise to never return as an enemy of the English people, a promise he held according to the chronicle. ${ }^{35}$

The ceremony at Andover was a confirmation (ad confirman$d u m),{ }^{36}$ because Olaf was already baptized, although this is not explicitly mentioned in the text. As a part of the ceremony, the bishop first led Olaf to Andover under great honours ( $h i$ pa laeddan Anlaf mid mycclum wurðscipe to pam cynge to Andeferan) and handed him ritually to King Ethelred, who received him from the bishop's hands (se cyng Æðelred his anfeng oet biscopes handa). ${ }^{37}$ The leading was a ritual act that was conducted during coronations in the Early Middle Ages in Scandinavia. The leading could take a variety of forms. The Magnússona saga reports how the Norwegian king Sigurd I Magnusson (OI Sigurðr Jórsalafari) visited a duke in Sicily. ${ }^{3}$ During a banquet, Sigurd led the Duke to the high seat and confirmed his royal title. In the Norwegian Hirdskraa, it is mentioned that the king shall take the hand of an earl and lead him to the high seat (pa skal konongr taka $i$ hond hanum oc scetia han $i$ hascete). ${ }^{39}$

The king had the function of godparent (or godfather; OE foeder) during the confirmation and exercised spiritual guardianship over Olaf, whereas Olaf could symbolically show that he could humble himself. The Christian tradition of a spiritual father might have originated in the mysteries of Isis, where a cult officiant had the function of meum iam, 'my father'. In Eastern Christianity, particularly, there was a conviction that a person was guided and instructed by a 'spiritual father', usually the bishop in a smaller congregation. Later, in early Europe, the importance of the spiritual father was reduced and should not be confused with a godfather. ${ }^{4}$

The ritual acts and the giving of hostages appear - as in the previous examples - as each other's prerequisites. The purpose of the confirmation ceremony might have been to display King Æthelred as the one with the highest rank. He had to avoid losing face. ${ }^{4 \mathrm{I}}$ And the siege of London had been a tactical victory for him if one is to believe the version of the Anglo-Saxon Chronicle, even if the 
siege as an incident does not need to be doubted. On the other hand, the payment of the Danish tribute was a significant loss for Æthelred, and the military and political situation was precarious. According to Joseph H. Lynch, Æthelred's intention was to complete the ceremony, a splitting up the Danes by binding Olaf to himself..$^{22}$ In any case, it may have been a symbolic prestige for Æthelred that Olaf outwardly submitted to the confirmation ceremony and then disappeared from his kingdom.

Why did Olaf submit to this ritual act of confirmation? One answer may be that he considered himself equal to the Christian Anglo-Saxon kings. On the other hand, they did not consider the Scandinavian rulers as equal. It was not until Canute the Great (ON Knutr inn ríki) became ruler of England that a king of Scandinavian birth was counted as an equal of English kings. ${ }^{43}$ If the case of Guthrum and Alfred was an example of submission, then this case was a situation that Olaf could use to his advantage, which had to do with the real political situation; there were different interests of the various participants in the ceremony. However, on a symbolical level the ritual acts were something people from the Scandinavian countries recognized, the oaths none the least. ${ }^{44}$ At the same time, there was another symbolism in the ceremony that could be related to the warrior elite, for example gift giving in the pre-Christian context. There is no direct correspondence to the confirmation ceremony, but according to Lynch, similar ritual acts, which marked paternity, may have existed in Continental Germanic areas. It may have been about cutting a young man's hair or beard or to give him his first weapon. ${ }^{45}$ It is obvious that it created a close bond similar to that of kinship. This method of using a symbolic relationship had a horizontal effect in this case because Olaf had (or was obliged) to leave Æthelred's territories in England.

In Part IV I will further show how relationships, including in a father-and-son-like relationship, as a social bonding mechanism, could have an impact on people who became hostages.

The hostages provided by Æthelred had the function of guaranteeing Olaf's personal security. There are no hints about what persons constituted the hostages. The hostage procedure can be compared with Lavelle's view that the hostage, as it appears in 
the writer's perspective of the Anglo-Saxon Chronicle, had only a practical role in guaranteeing Olaf's person. ${ }^{46}$ In my view, however, hostages, as described in the Anglo-Saxon Chronicle, may have had the function of honouring Olaf Trygvason. He was the one who had to come to Æthelred and not the opposite. In such cases, it is comparable to Lavelle's idea that the hostage should reflect the status of the hostage taker. ${ }^{47}$ Olaf was brought 'under honours' to Andover, which could indicate that the moment was perceived as a part of the same ceremony and thus a ritual act.

It is interesting that the hostages had to wait aboard the ships. The reason was probably pragmatic; it was the easiest way to control the hostages. But there was also a certain symbolism displayed. The ship was undeniable Scandinavian 'territory', and having the hostages there reinforced the impression that it was at the disposal of the Scandinavians and that they were dominant. $4^{8}$

As a result of these ritual acts, Olaf symbolically strengthened his social position. The symbolism was not about England, where he had no further political interests. ${ }^{49}$ The motivation would also have been strengthened by the part of the tribute that was given to Olaf. Consequently, the fulfilment of this holy promise could be seen as a performative act. And the performative actions became a reflection of the negotiations between the participants in the ceremonies (Olaf and Æthelred).

Thus, in this case the following ritual elements appear:

(I) The leading of Olaf to Andover under honours.

(2) The taking of hostages that would be related to Olaf's pride.

(3) The reception at Andover where Olaf was ceremonially attended by Æthelred.

(4) The actual confirmation.

(5) The giving of gifts.

(6) Olaf's pledge to never return to Æthelred's lands.

Everything is not evident from the description in the Anglo-Saxon Chronicle, but some ritual acts are merely implied or implicit in the text. All the ritual acts can be related to the negotiations 
that Bell considered being an important part of performativity. For both sides in the area of communication, in this case, it was important to demonstrate both power and humbleness. Such an order of power must, however, be understood on the basis of its political context, which can be seen through examples from the Carolingian Empire.

\section{Negotiations in the areas of confrontation in the Carolingian Empire}

Between the 8 th and Ioth centuries, there were numerous negotiations dealing with disputed land areas, plundering, and alliance-buildings between Danish rulers and the Carolingian royal power. These negotiations are reported in the Royal Frankish Annals (Annales regni Francorum). The following conflicts and peace processes involved the Danes: ${ }^{\circ}$

777. The Saxon Widukind does not appear before the court of Charlemagne in Paderborn. He is looking for a refuge with the Danish ruler Sigfred (or Sigurd Hring).

782. The emperor Charlemagne holds a meeting outside Cologne with the Saxons. Even the envoys of Sigfred attend.

804. The Danish ruler Godfred (or Gudfred) comes with a fleet to Sliesthorp (later Hedeby), at the border between Godfred's lands and the Saxons, to negotiate with Charlemagne. Emissaries are sent.

808. Godfred enters the land of the Obotrites with an army. Godfred returns and establishes the trading emporium Reric. He decides to fortify the boundary of his realm.

809. The Emperor is angry over Godfred's campaign. Godfred decides to reconcile and sends his men for a meeting with the Emperor's envoys (from the nobility) in a place north of Elbe so that both sides can express their views on the conflict. The negotiation ends in locked positions. At the request of Godfred, the Sorbian ruler Thrasco gives his son (Ceadragus) as hostage to the Danes. Godfred then summons troops, with auxiliary troops from the Saxons, and ravages the territory of the Veleti (or Wiltzes)..$^{5}$ Thrasco is later murdered by Godfred's men at Reric. 
8 Iо. Godfred's troops arrive to Friesland. All islands on the coast are invaded, and the Danes defeat the Frisians in three battles. The Frisisans have to pay Ioo pounds of silver in tributes. Charlemagne marches with an army to the mouth of the river Weser. Godfred withdraws but is murdered by one of his men. Hemming, Godfred's brother, takes over the throne and concludes a peace with the emperor.

8I I. A peace meeting is held at the river Eider with men from both the Carolingian Empire and the Danish realm.

$8 \mathrm{I}$ 2. Hemming dies. There is a war between Hemming's relatives Sigfred and Anulo. These two throne pretenders fight a battle where they are both killed. Anulo's party is victorious from the feud, and his brothers, Harald Klak and Reginfred, become kings. They ask the emperor for peace through messengers and make a request that their brother Hemming (a hostage?) is to be handed over.

8I3. A meeting occurs between Frankish, Saxon, and Danish noblemen above the river Elbe. The peace is confirmed and Hemming is handed over. Harald and Reginfred make a campaign in Britain. When they return, the son of King Godfred, together with some Danish great men who lives in exile in Sweden, starts a war against Harald and Reginfred. The kings are driven away.

8I4. Harald and Reginfred gather forces once again. New battles between Harald and Reginfred and the sons of Godfred. Reginfred is killed. Harald seeks support from the King of the Franks, Louis the Pious. Louis asks him to wait in Saxony for the right time.

8I 5. Louis raises forces with Saxons and Obotrites in support of Harald. They march over the river Eider into Sinlendi (Schleswig) and camp. Godfred's sons settle on an island 30 kilometres off the mainland. The forces of Louis and Harald fortify the coast and force the locals to give hostages to Louis. The sons of Godfred do not intervene.

8I7. Godfred's sons beg Louis for peace, but this is considered hypocrisy. Sclaomir (or Slavomir), ruler of the Obotrites, is in dispute with Ceadragus on shared royal power. Sclaomir breaks off from Louis and allies with the sons of Godfred. With the support 
of Danish troops, he falls into Nordalbingen and makes a siege on the border fortress Esesfelth. Finally, Sclaomir breaks the siege.

8I9. Sclaomir is sent to Louis in Aachen and is declared an outlaw. Ceadragus becomes ruler. Harald sails on the order of Louis to Denmark to take the power. Two of the sons of Godfred join him. Two other sons are driven out of the country.

82I. Harald and the sons of Godfred share the rule over the Danish realm.

822. Messengers are sent from both Harald and the sons of Godfred (who were driven away) to Louis.

824. Harald arrives at Compiègne and asks Louis for aid against the sons of Godfred, who threaten to throw him out of the country. Louis sends a delegation to negotiate with the sons.

825. Godfred's sons send a messenger to Louis, who decides that the peace they ask for will be settled with a meeting in their border regions.

826. Harald comes to Mainz and is baptized in the St. Alban's Abbey.

Over the Danish-Frankish (and Saxon) areas of confrontation, which consisted of border areas, several alliances and counter-alliances were formed between the Danes, the Franks, the Obotrites, and the Saxons. The Carolingian Empire's kings and emperors and the rulers of the Danes appear to have occasionally acted as reasonably balanced parties in negotiations.

The areas of communication consisted of temporary campsites that were prepared by the counterparties before the peace meetings. ${ }^{52}$ These places were often situated at watercourses, the rivers that formed natural boundaries. Characteristic to these areas was also the infrastructural effort by both the emperors and kings as well as the Danish rulers to consolidate their positions of power by fortifying their borders.

Boundaries can be considered as areas of communication within or in the immediate vicinity of the area of confrontation. Others were far from the areas of confrontation such as the emperor's 
base in Compiègne. The strengthening of the fortification line called Danevirke and the commercial site Reric - known archaelogical sites - can thus be characterized as attempts to regulate the areas of the confrontation. ${ }^{53}$

The construction of the trading place can be understood as the beginning of collaborative forms in accordance with step two of the model, although it may not have given immediate results. Short periods of calm, however, appear to have occurred, if one is to believe the Royal Frankish Annals.

For the counterparty, those who were plundered, there were regulatory means such as tributes to cope with the robbery. Hostages also filled the function of regulating areas of confrontation and could provide an opportunity as it could both be given by one party and used by the other to prevent further attacks. The actions of Thrasco, the ruler of the Obotrites, as described in the the Royal Frankish Annals is interesting in this case. After his son became a hostage of the Danes, he instead focused his interest on the Veleti. By uniting himself with the Saxons, he was able to plunder the lands of the Veleti. By the spoil he took and his new alliance, he could strengthen his failing position with his people. These acts are likely to have had a symbolic significance as well as pragmatic.

The above is intended as a characteristic of the area of confrontation and different communicative aspects. It also serves as the following analysis of why and under what conditions Harald Klak approached the king (or emperor) Louis the Pious at his court in Mainz.

\section{The alliance between Harald Klak and Louis the Pious}

Harald Klak's alliance with the king, later emperor, Louis the Pious, is depicted in a poem by Ermold the Black (Lat. Ermoldus Niegellus), called In honorem Hludovici emperatoris, 'In honour of Emperor Louis'. In 826, Harald (Lat. Herioldus) came with his family to Louis's court in Mainz (or Ingelheim). Then Harald and his family agreed to be baptized. ${ }^{54}$

The Emperor Louis the Pious (Fr. Louis le Pieux) personally dressed Harald during the baptism in the same way that he 
dressed recently converted men at the baptismal font. According to Lynch, this ritual act was specific to the Franks. ${ }^{55}$ Louis gave gifts in accordance with Harald's position, and afterwards they held a banquet. ${ }^{56}$ Interestingly, Lynch points out that one of the gifts consisted of French clothing with metals and precious stones that 'suited their taste'. ${ }^{57}$ What the Scandinavians thought of this symbolism we do not know. Probably it was a way for them to get acceptance, symbolically appearing equal, and above all to gain an alliance. This impression may have been reinforced at the baptism ceremony when the queen (or the empress) Judith stood as the godmother of Harald's wife, and Lothar, the emperor's son, was a sponsor of Harald's son. This can be compared with a remark by the historians Birgit and Peter Sawyer: the Franks perceived Denmark as a unit and not a land area ruled by two or several brothers..$^{58}$ There was not any hereditary title; the choice fell upon the person who could obtain support from the most dominant within the king's immediate circle, often after violent settlements. Thus, Louis may have thought he was dealing with a person with higher social capital than he might have, a person who, with this act, became subordinate in the vertical sense. For Harald there was nothing to lose. A few days after the banquet, Harald and Louis completed their alliance-building ceremony. Louis and Harald, now regarded as a 'godson', had then strengthened a friendship that they had begun already in 8I 4.59 These ritual acts can be perceived pragmatic and what later has been referred to as Realpolitik. The degree of submission by Harald Klak can be judged by relating to the conditions constituting a prerequisite for the area of confrontations with these constant alliances and counter-alliances. Compared to the conditions of Olaf Tryggvason's confirmation, the conditions for Harald were harsh: he had lost his position. Therefore, the role of the emperor as a sponsor can be emphasized to a higher extent than in the case of Olaf and Æthelred, in which it was about restricting Olaf from taking future tributes. Harald was given an expensive costume and the county of Rüstringen in Friesland. But Harald's position as a ruler of Rüstringen was unclear because it says in the annals that he could seek his refuge there with his household 'if necessary'. ${ }^{6}$ Nor were the families of Harald and the emperor intermarried. 
Most importantly, of course, was the assurance of a wider alliance and retaliation of Harald's power position in Denmark. Still, Harald became a weak ruler who only managed to retain power for a year. Then he retired to Rüstringen. ${ }^{6}{ }^{6}$ Although the giving of hostages was not a necessary measure in this particular case, some of the actions of Louis can be compared to step two in the model: During antiquity, the Romans 'invested' in the offspring of foreign rulers. This method was primarily applied to hostages from the eastern provinces and was ritually displayed in ceremonies. ${ }^{62}$ Similar methods and traditions might have continued into the Early Middle Ages. Louis's actions could likewise be understood so that he tried to show himself as a mediator of Christianity, as can be seen by the presence of the monk Ansgar - one of the earliest missionaries in Denmark and Svetjud - who travelled with Harald. It is worth noting the observation of Rimbert in Vita Ansgarii. Through a common belief in God, it would be possible with a more intimate friendship between the emperor and the Danish king. A Christian people could also aid Louis and his followers in their struggles. ${ }^{63}$

Between Harald and Louis, ritual acts took place, similar to those in England during the confrontations between the English and Scandinavian rulers. In this case, it was:

(I) Acceptance of baptism.

(2) Baptism (including sponsorship).

(3) Ritual dressing.

(4) The giving of gifts.

(5) Banquet.

(6) Symbolic confirmation of alliance.

Events also probably occurred, including rituals, that the sources do not mention, such as the oaths in connection with promises of alliance.

In order to further deepen the understanding of the above-mentioned ritual acts, one can compare this with Bell's commentary on how important symbolic acts are for those who compete for power, as ritual acts construct political submission and dominance. ${ }^{64}$ All this can be seen in the above case, as in the previous examples 
from confrontations between Anglo-Saxons and Danes. The one who possessed the most power was the one who could best determine the order and thus the direction of the display of power.

Everything indicates that the above cases exemplify a vertical subordination between a Scandinavian and a Carolingian ruler where the power relations were uneven. There are also examples of peace negotiations from other places, times, and power relationships in Scandinavia where rival rulers met on a more horizontal, equal level, and there were ritual acts with hostage of the same kind as in the Anglo-Danish and the Carolingian-Danish areas of confrontation.

\section{The peace negotiations between Harald Hardrada and Sweyn Estridsson}

In I064, the Norwegian king Harald Hardrada (ON Haraldr harðráði) and the Danish king Sweyn II Estridsson (Da. Svend Estridsen, ON Sveinn Ástríarson) met for a peace meeting at the river Göta älv. Two years earlier, Harald had defeated Sweyn in the battle of the river Nissan (in present Sweden) as described by the skald Pjóðólfr Arnórsson in the poem Sexstefja, which was a lausavisa composed in 1065 , a set of stanzas not connected to a grand narrative, which is now almost completely lost.

The later peace negotiations are depicted in a poem simply called flokkr (from ca. I064) by the skald Halli stírði (or striði, 'the stern'), reproduced by Snorri in the Saga of Harald Hardrada (OI Haralds [harðráða] saga Sigurðarsonar) in the Heimskringla. In the following analysis, I will rely on this skaldic poem to scrutinise the negotiations which were conducted over the area of confrontation between the two sides and how ritual actions and hostages were used by both sides in the area of communication, at the river of Göta älv.

In the poem, the second stanza describes how King Harald is a man to be trusted to keep his oath (eiðfastr Haraldr):

Gerðir opt fyr jǫðu eiðfastr Haraldr skeiðum.
Oath-fast Harald! Thou oft

Didst gird the land with ships. 
Sveinn skerr ok till annars eysund konungs fundar Út hefra lið lítit lofsnjallr Dana allra, hinn es hvern vág sunnan, hrafngrennir, lykr stǫfnum. ${ }^{65}$
Swein, too, through the sounds

Didst sail to meet the king.

The high-praised raven-feeder

Who locked up every inlet with stems Had out a mighty host

Of all the Danes from the South. ${ }^{66}$

(Transl. Erling Monsen \& Albert Hugh Smith)

The mentioning of the oath can be linked to the meeting between the two counterparties. The stanza also describes how Harald forms a blockade around his country and how the kings are about to face each other.

The poem's epithet for Harald as 'trustworthy' (eiðfastr) implies that the present peace meeting had a ritual meaning. As a prerequisite for the meeting, oaths had to be taken to preserve the peace. In the Saga of Harald Hardrada, it is mentioned that the peace meeting had been preceded by the sending of envoys between the two parties. ${ }^{67}$ Both sides respected the messengers. If the prose version of the Heimskringla is credible, it is implicit in the text that the messengers acted as witnesses of the assurances of the kings. And both kings agreed to meet at Älven (the river Göta älv), that is, at the border between the realms.

According to the third stanza of the poem, both sides approach the border (landamoeri) and agree to hold the meeting (moeltrar stefnu). ${ }^{68}$ There is no further information about the meeting place either in the prose text or in the poem. The meeting could have taken place on an island or on the mainland. If it was a meeting place that was organized ad hoc, it could be compared to my hypothesis about the mobile cult places that I presented in the introduction.

By relying on the theories on liminality by the anthropologists Arnold van Genneps and Victor Turner, it is possible to generally designate certain areas at borders as 'liminal'. ${ }^{69}$ In this case, such liminality could also characterize the meeting place where the political situation allowed the present householders (or farmers) from both sides to raise their voices. This arrangement can be related to Turner's hypothesis on 'Betwixt and Between', a kind of intermediate mode during ceremonies where opposition towards 
the authorities is possible. This kind of order might be seen in stanza 4 describing the meeting:

Telja họ́tt, es hittask, The brisk bonders said hvartveggja mjok, seggir, Such words loudly orð, paus angra fyrða Even such as, when men meet, allmjok, búendr snjallir. Most anger the others.

Láta peir, es praeta, pegnar, allt í gegnum, Men who quarrelled about everything svellr ofrhugi jofrum. eigi brátt við sọ́ttum.70

Did not want

To seek an early peace. The wrath of the princes grew. ${ }^{71}$ (Transl. Erling Monsen \& Albert Hugh Smith)

Great men were present during the meeting. The noun pegnar (pl.) is ambiguous as a poetic expression for 'men' or as a title. ${ }^{72}$ It seems as if there was opposition among the present great men towards the kings. According to the prose text, it was due to all the damage by the plundering people suffered during the war. ${ }^{73}$ The skald describes the wrath of the kings as 'dangerous' (Ofreið $i$ verðr jófra allhœet). The anger of the kings threatened to break the ongoing negotiation.

Some actors - other than the kings - had a significant impact on the outcome of the negotiations. In stanza 5 , it is mentioned that some managed to communicate between the different sides:

Ofreiði verðr jǫra allhæt, ef skal sættask. Menn peirs miðla kunnu, mọ́l ọll vega í skọlum. Dugir siklingum segja slíkt allt, es her líkar. Veldr, ef verr skulu hǫlðar, vili grindar pví, skiljask. ${ }^{74}$
The wrath of the princes would be perilous

If peace was in sight.

Had to weigh all in the scales.

It suited the kings to say

All such as the armies like.

Ill would result if the bonders

Were left in a worse position. ${ }^{75}$

(Transl. Erling Monsen \& Albert Hugh Smith)

It is noteworthy that these mediators were celebrated in this context. Obviously, they filled an important function in communicating the message between the king, the great men, and their men. The 
lines 5 and 6 of stanza 5 are key lines in this context, because it is said that 'It is honourable to say what the army considers' (Dugir siklingum segia slikt allt, es her likar), which is to be understood that the men were weary of the war and wanted to see an end of it. At the very least, the poem gives the impression that the kings appear as equal parties.

They also decided to give hostages to each other to secure the peace:

Hitt hefk heyrt, at setti

I have heard that gladly

Haraldr ok Sveinn við meinum, Did both Harald and Swein guð sýslir pat, gísla glaðr hvárrtveggi oððrum. Peir haldi svá sœrum, sọ́tt lauksk par með vọ́ttum, ok ollum frið fullum, ferð at hvọ́rgi skerði. ${ }^{76}$ Give hostages one to the other; God brought it about. May they keep their oaths And fully hold their peace. Nobody can break the treaty; It was sealed by witnesses. ${ }^{77}$ (Transl. Erling Monsen \& Albert Hugh Smith)

The giving of hostages was a result of the negotiations and - in this area of confrontation - gained the function of regulating both sides so that further violence could be prevented. It is likely that the hostages were left indefinitely. This case, however, is comparable to the Anglo-Saxon examples in which the giving of hostages was used to regulate future cooperation between different peoples in the Heptarchy and the Dane law.

A bilateral situation arose that can be compared to step three of the model (see Part I): after a long conflict, the two sides reached consensus under a certain pressure of other groupings such as the householders. Attempted mediation had been carried out and finally an agreement was accepted as legal by all the involved.

There are no hints of gift giving during these negotiations. But the skaldic poem of Halli stirði can be seen as a kind of gift that had been performed as a compliment during later hall ceremonies. In the poem, both rulers are attributed with similar characteristics of warriors and rulers as their heathen ancestors. These are the kennings and heitis for Harald and Sweyn. 
Harald: eiðfastr 'oath-fast', jofurr 'prince, wild boar'

Sweyn: ljófsnallr 'the honorable King', jofurr 'prince, wild boar', hrafngrennir 'raven-feeder'

These are examples of how traditions of old age survived into the time when Christianity was accepted in Denmark and Norway. There are also examples of meetings between heathens and Christians in Norway where there was a consensus about the ritual acts that were linked to the actual peace negotiations, while the confrontation between 'belief systems' appears to have been more loaded with subjective judgements.

\section{The hostages of Dale-Gudbrand}

In the Heimskringla (Ch. I I I-I I 3), in the saga of Olaf Haraldsson, it is reported that the Norwegian king Olaf II Haraldsson (later St. Olaf) - with his said ambition to Christianize and to conquer the whole of Norway - raids the county of Oppland. Olaf relies on bases in places like the regions of Dovre and Lesja. He forces the inhabitants of the Oppland to accept Christianity and give their sons as hostages.

In the Gudbrand Valley (No. Gudbrandsdalen), lives the heathen chieftain (ON hersi) Dale-Gudbrand (ON Dala-Guðbrandr) at a farm called Hundtorp around IO2I. He sends his son with a retinue of householders against Olaf and his men. But the householders fly after a few spearthrows from Olaf's men and Gudbrand's son is caught. Olaf gives the son mercy and he is sent back to his father with the announcement that the king shall soon come to the thing at Hundtorp.

The son tells his father of Olaf's skills as warrior and advises Dale-Gudbrand to submit. Dale-Gudbrand refuses. During the night Dale-Gudbrand has a horrible dream of a terrible shape that mentions that he and all his men will die if they do not submit to King Olaf. The next day Tord Bigmaw (OI Pórðr istrumagi), who is a cult functionary called hófgóði, tells Dale-Gudrand that he had the same dream. ${ }^{78}$

[-] In the morning they had a thing called and said that it seemed advisable to them to hold a thing with this man who came from 
the north with new words of bidding and get to know with what truth he fared. Then Gudbrand said to his son: 'Thou shalt now go to the king who gave the peace, and twelve men with thee'; and so it was done. And they came to the king and told him their errand that the bonders would hold a thing with him and make peace between the king and the bonders. The king said it seemed a good thing to him, and they now bound it with terms between themselves for as long as the meeting should last. After they went back and told Gudbrand and Tord that peace was made. The king then went to the place which was called Lidstader and was there five nights. Thereupon the king went to meet the bonders, and held a thing with them, but there was much rain that day. When the thing was set the king stood up and said that the folk in Lesjar and in Loar and in Vaga had taken Christianity and broken down their temples of blood offerings, 'and now they believe in the true God who shaped heaven and earth and knows all things'. After that the king sat down and Gudbrand answered: 'We know not of whom thou talkest. Thou callest by the name of God Him whon neither thou nor anyone hast seen. But we have a god whom we can see every day; he is not out to-day, because the weather is wet. He will seem awe-inspiring and mighty to thee and I think fear will come upon thee when he comes to the thing. But since thou sayest that thy God can do som much, let Him now do so that the weather to-morrow be cloudly without rain, and let us than meet here'. The king then went home to his room, and Gudbrand's son went with him as hostage, but the king gave them another man in return. In the evening they asked Gudbrand's son how their god was made. He answered that 'he is marked like Thor and he has a hammer in his hand, is big of build and is hollow inside, and there is a stand on which he rests when he is outside. There is no shortage of gold and silver on him, four loaves of bread are brought to him, and meat withal'. After that they went to bed, but the king awoke in the night and was at his prayers. But when it was day the king went to Mass and then food and so to the thing; the weather was now such as Gudbrand had wished for. ${ }^{79}$

(Transl. Erling Monsen \& Albert Hugh Smith)

One day later at the thing, the sun rises and King Olaf refers to it as his god before the heathen householders. One of Olaf's men, Kolbeinn, breaks down the idol of Thor. When the idol breaks apart, mice, lizards, and snakes crawl out. The householders ${ }^{80}$ are 
frightened and convinced of the incapability of their god. They accept the king's friendship and Christianity. The bishop of Olaf baptizes Gudbrand, his son, and all other inhabitants of the valley. A church is later built in the Gudbrand Valley. ${ }^{8 \mathrm{I}}$ The legendary saga of St. Olaf was probably written around I2 IO. Snorri Sturluson possibly had this version as the model of his version in the Heimskringla (cf. Figure III.2). Even though it is disputed, there may have been an older, now lost, version of the saga of St. Olaf, probably written around I I90, which Snorri may have relied on.

Previous research has often referred to the episode of DaleGudbrand's confrontation with King Olaf, but the episode has not been subject to an extensive analysis, except for the one made by the historian of religions Gro Steinsland. She has thoroughly analysed the episode in the Heimskringla called 'the drama of Hundtorp' and pointed out the lack of interest among researchers. ${ }^{82}$ Previous research has focused on the source value of the story, which is now generally considered to be low. ${ }^{83}$

For researchers in the early I900s, such as the historian and politician Edvard Bull, the story was important as a part of the confirmation of an early state formation. For him it was important that it was a Norwegian history. Bull stated that Snorri used a local legend and that archaeological evidence such as burial mounds and stone settings indicated a central place. Additional

The oldest saga of St. Olaf, ca. I I90, mainly lost.
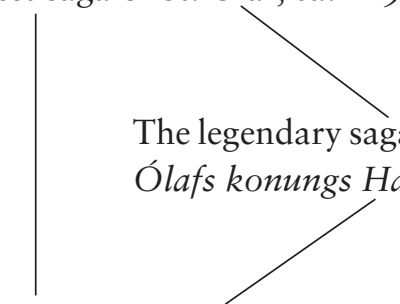

The legendary saga of St. Olaf (ca. I 2 Io, Helgisaga Ólafs konungs Haraldssonar)

Saga of Olaf II Haraldson (Óláfs saga helga) by Styrmir Kárason (ca. I220, mainly lost)

Saga of Olaf II Haraldson in Heimskringla (ca. I230)

Figure III.2. The possible relation between an original, now lost, saga of St.

Olaf and later versions. 
evidence was found in place names, skaldic poetry, and medieval diplomas. $^{84}$

More recent researchers are more concerned about whether it is really a Norwegian story. The philologist Theodore Andersson argues that the oldest story of St. Olaf was not the original source. Instead, it may have been built on the presumed *Kristni páttr, which might have been written around I $210 .{ }^{85}$ The story is therefore Icelandic and not Norwegian. Perhaps the Icelandic chronicler Ari Porgilsson may have written this part, which was later used by both Snorri and the author of the legendary saga of St. Olaf. Andersson tries to show how some specific Christian ideas might have inspired Snorri in the miracle-like events of the Heimskringla version.

Steinsland refers to the philologist Anne Asplin, who analysed the manuscript of the episode with Olaf Haraldsson and DaleGudbrand. According to Steinsland, Asplin succeeds in distinguishing some Norwegian linguistic features. ${ }^{86}$ The depiction of the landscape could indicate the Norwegian origin of the story. Steinsland therefore assumes that the story may be built on a local tradition. ${ }^{87}$ She interprets the episode with Olaf and DaleGudbrand as a way of reproducing an ideal picture of how a Christian Germanic king would appear. ${ }^{88}$ According to Steinsland, following the theologian James C. Russell, Christianity brought new means to kings of Norway, including the stave churches and a general ritualization of the traditions of the saints. This kind of Christianity was characterized by a salvation ideal in which apocalyptic ideas were central. In the 'Germanic communities', the old tradition (forn siðr) touched upon the cultural identity and solidarity of the groupings. ${ }^{89}$ The new tradition (inn nýi siðr), i.e. Christianity, had to be adapted to the old identity and solidarity. Through the new Christian ideal, Christ was interpreted as a conquering warlord; on early Scandinavian crucifixes he is depicted as a king with a golden crown. It was also important to show Christ as a victor who defeats the dark powers, often regarded as being embodied in the old, indigenous deities. ${ }^{90}$

I agree with Steinsland that one cannot completely deny the possibility that Snorri built on sources that may have been unknown to us, but the story itself must be seen in the light of the ambition 
to make Olaf Haraldsson a saint and cannot be taken for a realistic account. Writers like Snorri tend to focus on religious matters such as the worship of heathen gods, which is set in opposition to the Christian doctrine of a 'true god'. For me, however, it is not the Christian conversion but the interaction between the actors that is interesting. Certain aspects of the story may be authentic regarding the use of hostages and references to older legal traditions. Because the versions in the Heimskringla and the legendary saga cannot be regarded as realistic accounts of all the events, there is the possibility that the medieval writers did not see any threat to parts in the story that was no direct challenge to the conversion and the adoption of the new tradition.

Below, I outline the traditions in the stories that can be related to hostages and the traditions of assemblies like the things and how these can be understood against Christian literary traditions. To clarify, a division of the events in the story can be made into sequences:

(I) The summoning to the thing. Dale-Gudbrand sends his son with twelve men to invite King Olaf to the thing.

(2) King Olaf accepts the invitation.

(3) The son returns to Dale-Gudbrand and confirms that there is a truce (grið).

(4) The king travels to the farm Listad (Liðsstaðir) and remains there for five days.

(5) The first day of the thing. ${ }^{9 \mathrm{I}}$ The kings speak and proclaim his new faith. Dale-Gudbrand gives his answer. Both the king and Dale-Gudbrand give hostages. Dale-Gudbrand sends his son with the king to Listad.

(6) The second day of the thing. At dawn the king visits the mass, eats his morning meal, and walks to the thing.

(7) The third day of the thing. The king demonstrates that his faith is the strongest. When the sun rises, the idol of Thor bursts and mice, lizards, and snakes crawl out.

The sequences can be interpreted in the following way:

Sequence I. That there were just twelve men may have had Christian connotations; Jesus had twelve disciples. According to 
Theodore Andersson, these manœuvres with military movements are just a way to dramatize the end of the story. ${ }^{92}$

Sequences 2-4. Even if the story does not refer to real events, this (ritual) act itself does not need to be 'dramatized' but may be consistent with previous examples of peace processes in the Anglo-Danish areas of confrontation.

Sequence 5. It seems that Snorri, in other chapters about Olaf's life, reports how he paid his respect to old laws and traditions during various assemblies even if the king's word was final, even this information must be taken with a grain of salt. At the same time, Steinsland points out that the king also opposed the householders on occasions by violating their old traditions (brióta log vár). ${ }^{93}$

Sequence 7. As the sun rises and the idol of God breaks, it is according to Gro Steinsland - a sign of the power of the majestas, 'the divine monarch'. ${ }^{94}$ It is not a question about salvation or condemnation but rather relates to early Christianity in which the ruler identified himself with Christ. When the saints break down idols, the devil can materialise in the form of a dragon or worm.

It is possible that the king is presented in the text according to a Rex Justus ideal, i.e. the 'righteous king', whose power stems from his piety. ${ }^{95}$ On the other hand, it is not certain that just the giving of hostages and other ritual acts upon the summoning to the thing are inaccurately described, even if the story itself is fictitious. Before Snorri, these kinds of traditions were not an immediate threat to the new tradition. On the contrary, the above example, with hostages, illustrates that it occurs in situations where both parties respect the hostages for different reasons. It is rather how the fight is made between the counterparts that are important to the writer and that the Christian faith appears as the strongest when heathen gods are positioned against the Christian god. The traditions that are not a threat to the king as Rex Justus is of less importance in Snorri's account. The procedure with the hostages certainly follows this line. Dale-Gudbrand dare sends his son, which was a sign of respect and trust. The noun einkamál can be interpreted as a 'pledge' or 'promise'. ${ }^{96}$ Thus, the actual negotiations and the actions associated with the conflict are overlooked. This does not mean that the description would generally 
be free from idealization or influence from literary traditions and Christian values, a topic that we will return to.

\section{Some characteristics}

The similarities between Heimskringla's version (Hkr) of the Saga of Olaf II Haraldson, The Anglo-Saxon Chronicle (ASC), Halli's Flokkr (F), Asser's (A) Biography of Alfred and the Royal Frankish Annals (Fk) can be structured as a series of events of ritual acts involving hostages and other ceremonies that took place in the context of negotiations of peace:

(I) Messengers and envoys are sent.

[Hkr, ASC, A, F, Fk]

(2) An agreement of where to meet. The [Hkr, ASC, F] promise not to break the peace at the meeting place.

(3) The giving and taking of hostages performed at an area characterised by liminality, which could be:
(a) a river (b) an area of communication such as the thing. The hostage giving took place:
[Hkr, ASC, F, A, Fk]
$(\alpha)$ before $(\beta)$ during or $(\gamma)$ after the meeting.
(4) Negotiations at:
(a) assemblies such as the thing or
[ASC, A]
(b) in the hall (or the royal court)
[Hkr, F]
[Fk]

(5) Ritual actions, including:
(a) the giving of gifts
[ASC, Fk]
(b) oaths/promises
[ASC, Hkr, A]
(c) the performances of skaldic poetry or other celebrations
(d) baptism
[ASC, A, Fk]
(e) the casting of lots
[Hkr]
(f) other types of demonstrations
[Hkr, Fk]
(6) Festivities.
[ASC]

(7) Hunt. 
Some of the above-mentioned ritual acts have not been touched upon. This applies to the casting of lots, alternatively dice games, and the possible hunt (see above). The casting of lots, however, is mentioned in the Heimskringla and some other sources. For example: Olof Skötkonung and Olaf Haraldsson play dice as to whether the island of Hisingen should belong to Norway or Sweden. ${ }^{97}$

What is refered to as 'peace process' in this survey could extend over several years, as the examples from the Anglo-Danish and Frankish-Danish areas of confrontation show. Therefore, it may not always be right to describe the ritual acts as one ceremony, rather there were acts that occurred with many years apart. The ritual actions can be related to the three steps of the model:

(I) The establishment of social relations through ritual actions.

(2) The stabilization and establishment of (new) trade relations and other types of economic cooperation.

(3) The peace treaty is ratified by both parts.

The middle step is visible to a lesser extent in the examples I have discussed. The peace agreement between Guthrum and Alfred, as well as the statistics of the Íslendingabók and the Landnámabók, provide empirical evidence that economic cooperation really occurred between opposing sides. The relationship between steps one and three is marked by the time that occurred between the establishment of the contact and the meeting. The first contact was ritually conditioned by the promise of no further hostilities and to keep the peace at the meeting place. Step one could also include all of the above-mentioned ritual actions. Step one may also have resulted in a temporary truce. Sometimes it took a long time, with interruptions for fighting, before the peace agreement could be completed, that is, step three. Then other interests from various groupings, as in the case of Harald Sigurdsson and Svend Estridsen, could have had an effect on the outcome.

Through the ritual acts, there was room for different power demonstrations that were symbolically important and were performed in ritual acts. Some of these ritual actions may not fit into 
a normal pattern for what is commonly referred to as 'ritual' but can still be compared to what Bell refers to as 'ritual-like'. On the other hand, many researchers are willing to see gift-giving as a ritual act in ancient Scandinavian traditions.$^{98}$ Mauss, for his part, was willing to see the gift in Germanic societies as something that also included acts like hostages and marriages. He described the 'Germans' as loosely organized tribal communities that 'communicated' through gifts. The alliances were based on pledges and hostages, as well as celebrations and gifts that were as generous as possible. ${ }^{99}$ Even though Mauss did not relate these actions to peace processes, as I do, he still attributed to them a symbolic value within social systems. The symbolic value was contextual; the giving of gifts, which could include enormous sums (i.e. the Danegeld), must at that time be submitted in such a way that it marked generosity in return for promise (not to return, not to plunder, etc.). Even ritual acts such as baptism and confirmation became means that a Christian ruler could use to symbolically demonstrate his supremacy before the great men/nobility, the ecclesiastical power, or the assembled commonality.

The source material suggests that a heathen ruler could understand the demonstrations. Such a demonstration can be seen in the peace meeting in 9I I between Rollo, identified as the Norwegian Gaange Rolf (ON Gengu-Hrólfr), and the French King Charles the Simple (Fr. Charles le Simple) at the agreed site of St Clair, Normandy. ${ }^{100}$ The armies stood on each side of the river Epte. According to the historian and dean Dudo of Saint-Quentin (d. I043), Rollo sent an archbishop with the message of the lands he wanted. After several bids, the king finally promised that Rollo would get Brittany beyond the land area he already had. The king passed this information to Rollo by sending Duke Robert and Bishop Franco as envoys. Rollo then followed them to Charles, a hostage was given for his safety, and oaths for safe conduct were sworn. At the request of the Franks, Rollo put his hands on Charles's knee, something Rollo did not do for anyone else earlier, including his father, according to Dudo. The king gave his daughter Gisla as wife to Rollo and the land from Epte to the sea as agreed upon. But Rollo did not accept another humiliating act: to kneel down and kiss the king's foot. In Rollo's place, one of his 
men went forward and took the king's foot to his mouth, leaving Charles fallen on his back to the amusement of the surroundings. This is a dubious story because Dudo lived several decades after these events and had to rely on second-hand information. William of Jumièges (Fr. Guillaume de Jumièges, d. I070), a follower of Dudo, does not mention the episode with the foot. ${ }^{\text {ror }}$

Because the cases mentioned in this part mainly occurred between Christians, or between Christian and heathen rulers, it is tempting to understand the cases as what we refer to as 'religious' in a Christian sense. Still, the perception of what was symbolically valuable may have differed from case to case; the 'heathens' interpreted the situation in a different way than the Christian writers did. Obviously, there were room for spontaneous, demonstrative expressions of power or other expressions that might be perceived as more important to the actors. The historian Gerd Althoff points out that the 'non-verbal' actions were part of such demonstrations and they also meant to demonstrate peaceful intentions. ${ }^{102}$ Additionally, the actions followed so closely that the dividing line between the sacred and the profane became fluid; it is therefore possible to describe them generally as ritual acts.

The ritual acts were thus a part of the situation of realpolitik, something that can be seen in the cases listed above. To speak with Bell, the ritual acts became something that both sides constructed from their perspective. ${ }^{103}$ The conflicting parties went stronger from the ceremony but could use it differently to later gain political benefits. In this way not only were societies changed through the ritual acts, but the future relationships between individuals and societies were also affected. The way the hostage was treated may also be associated with important symbolic mechanisms. These issues will be addressed later in this book.

\section{Concluding remarks}

In this part various examples of confrontations involving hostages are given. The areas of confrontation that is described occurred in present England, France, and Denmark. The examples are compared to the model presented in Part I. 
The Dane law was ruled by factions of leaders and competitive groupings with different interests. The giving of gifts, trade, peace treaties, and the use of hostages were all used to affect the out come of peace processes and thus the building of alliances. A special function of the use of hostages, in this case, was its availability as a personal security on request. Ceolwulf was given the rule of Mercia. In exchange he made sure that a hostage was always available to the Danes. According to the agreement he was also ready to support the Danes with forces on request.

The use of hostages could also be symbolical. The kings Sweyn Forkbeard from Denmark and Olaf Tryggvason from Norway were to receive the Danegeld from the king of Wessex in 994. Hostages were exchanged and other rituals were perfomed when Olaf arrived to Andover. Olaf was ritually led to the king by the bishop and was confirmed. Thus, rituals, or ceremonies, like these - that occurred in the Anglo-Danish area of confrontations contained ritual acts like the use of hostages, oath-takings, baptism, and gift-givings. Both Olaf and the English ruler could symbolically benefit from these rituals. There are similarties in the alliance between Harald Klak and Louis the Pious in the Frankish-Danish area of confrontations. As a part of the ceremonies, Louis personally dressed Harald during his baptism. This was a ritual act that was specifically important to the Franks. Rituals like those could be perceived as part of a realpolitik in which Scandinavian rulers searched for support from continental rulers without caring so much about the old traditions of their home lands. It was more attractive to have the continental rulers as models.

In I064, the Norwegian king Harald Hardrada and the Danish king Sweyn II Estridsson met for peace negotiations at the river Göta älv. In a poem by Halli stírði, the negotiations are reported: It was decided about the hostages and how the boundaries would be drawn. In this case the use of hostages was linked to the establishment of the borders. During the negotiations, the householders were able to speak their minds about the outcome of the negotiations, and they were able to restrain the rulers from further hostilities. This was an important part of the negotiations: the representatives of the peoples had the ability to affect the outcome of the peace. As a comparsion, this is not evident from the story 
about the negotiations between Olaf Haraldsson and the heathen chieftain Dale-Gudbrand as reported by Snorri in Heimskringla. Because the story is about Saint Olaf, it focus on themes such as the Rex Justus-ideal and the conversion of the heathens rather than rituals that surround the negotiaitons. In the story, DaleGudbrand dares to send his son as a hostage during the negotiations, which could be interpreted as a token of trust and thus something that is subordinated to the main theme, the conversion of the heathens, but nonetheless important in the reality.

It is thus in these contexts that the giving and taking of hostages must be understood as a ritual act about symbolic demonstrations of power. However, the purpose of a hostage as a symbolic show (or demonstration) may have varied. The role of the hostage did not end with the peace negotiations themselves. On the contrary, it may have played a symbolic role in embellishing the triumph of the victor, who was exposed many times in different ways, not least in the hall where the status of the ruler was constantly confirmed by skalds and various festivals that included many ritual acts.

\section{Notes to Part III}

I. The Medieval Life of King Alfred the Great (ed. Smyth): 22 (Ch. 47).

2. This giving of hostages is not mentioned in the MS A (see The Anglo-Saxon Chronicle MS A [(ed.) Bately]: 50 [year 876]).

3. A white bandage - or a hair tie - was knot around the head of the one who was going to be baptized. Before that, he or she was greased with oil. The bandage was removed a week later.

4. The Anglo-Saxon Chronicle MS E ([ed.] Irvine): 48 ff. (year $865-$ 878); The Anglo-Saxon Chronicle MS F ([ed.] Baker): 66 ff. (year $865-878)$.

5. As, for example, the division of the Great Heathen Army in 87I.

6. The Danegeld was raised in 99I. In France, however, the tradition occurred even earlier (the ninth century). The Danegeld may be similar to a tax system, which means that there was also some kind of 
counterperformance service in return, for example military protection (Larsson 2008: 7I).

7. Cf. the years $867-877$ in the timeline.

8. See the introduction.

9. The Welsh monk Asser (see Asser, The Medieval Life of King Alfred the Great [(ed.)] Smyth]: 22 [Ch. 46]) have another explanation of the hostage taking by the Danes:

After he had been expelled, the Pagans subjected the whole kingdom of the Mercians to their rule. But they entrusted not it to the agreed custody of a certain foolish thegn, whose name was Ceolwulf, on the deplorable condition that if they wished to have it again at any time, he should give it peaceably to them. He gave hostages to them under this provision and he swore that in no way would he go against their will but that he would be obedient to them in all things.

(Transl. Alfred P. Smyth)

IO. Cf. Kosto 2012.

I I. See Part I.

I2. See Part VI.

I3. See Part I.

I4. Hill 200I: I73 ff., I 82.

I 5. Lavelle 2006: 280 .

I6. Lavelle 2006: 280 .

I7. Lavelle 2006: 280 .

I 8. See Part IV. The promise is repeated in several chronicles.

I9. Cf. Lavelle 2006: $280 \mathrm{f}$.

20. See Parts I, IV.

2I. See Part I. Cf. step two of the model.

22. It is quite possible that the meeting took place in some hall or fortification in Wareham, but we can only speculate about the location. However, it is impossible to imagine that the Danes would have 
performed at something similar to the cultic building of a hof in Wareham, where the ring would have been kept and oaths would have been sworn as described in the Eyrbyggia saga. See Sundqvist 2007: I75 ff. and Olsson 20I 2: $68 \mathrm{ff}$. for evidence and a discussion about rings and oaths.

23. Regarding morality and ethics associated with hostages, see Part IV 24. Asser, The Medieval Life of King Alfred the Great ([ed.] Smyth): 23 (Ch. 49).

25. See Parts I, III, IV in this volume.

26. Cf. Ginzburg's (1989) remarks.

27. Lavelle 2006: 280.

28. See Part I.

29. Lavelle 2007: 75 .

30. Lavelle 2007: 73 .

3. Lavelle 2007: 73 .

32. According to David Hill (200I: I $8 \mathrm{I}$ ), the hunting lodges of the kings of Wessex also occupied the border areas between Wessex, Wales, and Cornwall. One reason may have been that these areas were not settled due to raids and plundering. The wastelands were therefore suitable as hunting areas. Cf. the theoretical discussion in Part I.

33. Haywood i995: i I I f.

34. See Part IV where I discuss the sum I6,000.

35. Anglo-Saxon Chronicle MS F ([ed.] Baker): 89 (year 994).

36. Anglo-Saxon Chronicle MS F ([ed.] Baker): 89 (year 994).

37. Anglo-Saxon Chronicle 7 MS E ([ed.] Irvine): 6I f. (year 994).

38. Heimskringla III ([ed.] Bjarni Aðalbjarnarson): 247 (Ch. 28).

39. Hirdskraa ([ed.] Imsen): 82 (text), 83 (transl.) (Ch. I I).

40. Lynch I986: I65, I68.

4I. Cf. Lavelle 2006: 285 . 
42. Lynch I998: 225 .

43. Haywood I995: II3.

44. See Sundqvist (2002: 324) on the continuity of oaths into Christian times in Scandinavia.

45. Lynch I986: I80.

46. Lavelle 2006: 289 .

47. Lavelle 2006: 295 .

48. Cf. Parts I, IV.

49. Cf. Larsson M. G. 2008: 55 .

50. Den frankiske Rigsannaler, Vikingerne i Franken ([ed. and transl.] Albrechtsen): I I-24 (years 777-826).

5I. The tribal federation of the Veleti had its settlements east of the Obotrites and was from the late ninth century named as the Lutici. They were divided into different tribes: the Kessinians of Lower Warnow, the Zirzipanians (alt. Circipanians) between the Recknitz, Trebel, and Peene rivers, the Tollensians to the east and south of Peene, and the Tollense and the Redarians to the south and east of Tollensee and Upper Havel (Die Slawen in Deutschland [(ed.) Herrmann]: 8).

52. Compare the discussion about mobile cult places in the introduction.

53. Through the construction of a trading venue there, it was possible to impose duties and other means of taxing goods. The control of land areas based on the fortifications meant that there was an opportunity to demand land interest rates, or similar taxation systems or similar forms of taxation, although such systems were characteristic of the late Viking era and the early Middle Ages. However, some form of primitive taxation system was used (see Part IV on taxation systems).

54. Ermoldus Nigellus, In Honor of Louis, Charlemagne and Louis the Pious ([ed.] Noble): I76 ff. (Book 4).

55. Lynch I986: I75 f.

56. Ermoldus Nigellus, In Honor of Louis, Charlemagne and Louis the Pious ([ed.] Noble): I 78 ff. (Book 4). This ceremony is reported by 
Rimbert too in Vita Ansgarii. (Boken om Ansgar [(ed.) Hallencreutz]: 22 [Ch. 6]).

57. Lynch I986: I76.

58. B. \& P. Sawyer I993: 52.

59. Lynch I986: I76.

60. Den frankiske Rigsannaler, Vikingerne i Franken ([ed.] Albrechtsen): 24 (year 826).

6I. Den frankiske Rigsannaler, Vikingerne i Franken ([ed.] Albrechtsen): 25 (year 828).

62. See Parts I, IV.

63. Boken om Ansgar ([ed.] Hallencreutz): 22 (Ch. 6).

64. Bell I997: I33 ff.

65. Haralds saga Sigurðarsonar, Heimskringla III ([ed.] Bjarni Aðalbjarnarson): I 59 (text) (Ch. 7I).

66. The History of Harald Hardrade, Heimskringla, Or the Lives of The Norse Kings ([ed.] Monsen \& Smith): 550 (transl.) (Ch. 7I).

67. Haralds saga Sigurðarsonar, Heimskringla III ([ed.] Bjarni Aðalbjarnarson): I 59 (Ch. 7I).

68. Haralds saga Sigurðarsonar, Heimskringla III ([ed.] Bjarni Aðalbjarnarson): I60 (text) (Ch. 7I).

69. van Gennep I977: Io ff.; Turner I969: 94-I30.

70. Haralds saga Sigurðarsonar, Heimskringla III ([ed.] Bjarni Aðalbjarnarson): I60 f. (text) (Ch. 7I).

7I. The History of Harald Hardrade, Heimskringla, Or the Lives of The Norse Kings (ed. Monsen \& Smith): 55 I (transl.) (Ch. 7I).

72. There is another example of opposition from great men and the assembly present at the thing. At the thing of Uppsala, Torgny lawmen spoke against king Olof Skötkonung and even threatened him (Óláfs saga helga, Heimskringla II [(ed.) Bjarni Aðlarbjarnarson]: I 4 ff. [Ch. 80]). Even though there were different political conditions in the Swedish, Danish, and Norwegian realms, this type of 
opposition still seems to have been a prerequisite for the function of the things, otherwise they would not have been needed.

73. Haralds saga Sigurðarsonar, Heimskringla III ([ed.] Bjarni Aðalbjarnarson): I60 (text) (Ch. 7I).

74. Haralds saga Sigurðarsonar, Heimskringla III ([ed.] Bjarni Aðalbjarnarson): I6I (text) (Ch. 7I).

75. The History of Harald Hardrade, Heimskringla, Or the Lives of The Norse Kings ([ed.] Monsen \& Smith): 55 I (transl.) (Ch. 7I).

76. Haralds saga Sigurðarsonar, Heimskringla III ([ed.] Bjarni Aðalbjarnarson): I6I f. (text) (Ch. 7I).

77. The History of Harald Hardrade, Heimskringla, Or the Lives of The Norse Kings ([ed.] Monsen \& Smith): 55 I (transl.) (Ch. 7I). 78. Kap. I I 2

[-] Ok um morguninn létu peir blása til pings ok sogðu peim pótti pat ráð, at eiga ping við pann mann, er norðan fór með ný boðorð, ok vita með hverjum sannendum hann ferr. Síðan mælti Guðbranðr við son sinn: "Pú skalt nú fara á fund konungs pess, er pér gaf grið, ok xii. menn með per" -ok svá var gęrt. Ok peir kómu á fund konungs ok segja honum sitt Ørendi, at boendr vildu hafa ping við hann ok setja grið í mílli konungs ok bónda. Konungr lét sér pat vel pokkask, ok bundu pat við hann einkamálum sín í milli, meðan sú stefna væri; ok fóru peir aptr við svá búit ok segja Guðbrandi ok Pórði, at grið varu sett. Konungr fór pá til boejar pess, er Liðsstaðir heita, ok var par v. nætr. pá fór konungr á fund búanda ok atti ping við pá; en væta var á mikil um daginn. Síðan er pingit var sett, pá stóð konungr up ok segir at Læsir ok á Lóm, á Vága haft tekit við kristni ok brotit niðr blóthús sín -"ok trúa nú á sannan guð, er skóp himin ok jơro ok alla hluti veit”. Síðan sezk konungr niðr, en Guðbrandr svarar: "eigi vitum vér, um hvern pú roeðir; kallar pú pann guð, er hvern má sjá, ok er pú sér eigi ok engi annara, er vér eigum pann guð, er hvern dag má sjá, ok er pví eigi úti í dag, at veðr er vátt; ok mun yðr hann ógurligr sýnask ok mikill fyrir sér, vænti ek, at yðr skjóti skelk í bringu, ef hann kømr á pingit. En með pví at pú segir, at guð yðarr má svá mikit, pá láttu hann nú svá gera, at veðr sé skýjat í morgin, en regn ekki, ok finnumk hér pá”. Síðan fór konungr heim til herbergis, ok fór með honum 
sonr Guðbrandz í gísling, en konungr fekk peim annan mann í móti. Um kveldit pá spyrr konungr son Guðbrandz, hvernug goð peira væri gǫrt. Hann segir han var merkðr eptir Pór - "ok hefir han hamar í hendi, ok mikill vexti ok holr innan, ok gọrr undir honum sem hjallr sé, ok stendr han par á ofan, er hann er úti; eigi skortir hann gull ok silfr á sér; iiii. hleifarbrauðs eru honum foerðir hvern dag ok par víð slátr”. Síðan fóru peir í rekkjur, en konungr vakði pá nótt ok var á boenum sínum. En er dagr var, fór konungr til messu ok síðan til matar ok pá til pings; en veðrinu var svá farit, sem Guðbrandr hafði fyrir mælt. Óláfs saga Helga, Heimskringla II ([ed.] Bjarni Aðalbjarnson): I 86 f. (Ch. I I2).

79. The History of St. Olav, Heimskringla, Or the Lives of The Norse Kings ([ed.] Monsen \& Smith): 33 I (transl.) (Ch. I I 2).

8०. By 'householder' I here refer to the OSw bondi, ON bóndi, which also could be interpreted as 'farmer'. The ON bóndi is from the present participle of búa ('to reside').

8I. Olav den heliges saga, Nordiska kungasagor II ([ed.] Johansson): I 56 f. (Ch. II2).

82. Steinsland 2000: I I9.

83. See Steinsland 2000: I I9.

84. Bull I9I7: I 58 ff.; Engen 2010: 3 I.

85. T. M. Andersson I988: 265.

86. Steinsland 2000: I I 8.

87. Steinsland 2000: I I9.

88. Steinsland 2000: I 2 I, I23, I $27 \mathrm{ff}$.

89. Steinsland 2000: 90.

90. Steinsland 2000: $90 \mathrm{f}$.

9I. According to the local historian Arnfinn Engen (20I0: 3I), the thing place was probably situated nearby the farm of Hundtorp. After the Christianization, the thing was moved to the mountainside above Hundtorp.

92. T. M. Andersson I988: 83 . 
93. Steinsland 2000: I 26.

94. Steinsland 2000: 123.

95. See the discussion in Steinsland 2000: 104.

96. Íslensk orðabók I992: 167.

97. Óláfs saga helga, Heimskringla II ([ed.] Bjarni Aðalbjarnason): I 57 (Ch. 94).

98. See Sundqvist 2002: $204 \mathrm{ff}$.

99. Mauss 2002: 77.

ıoo. Normandiets historie under de forste Hertuger ([ed.] Albrechtsen): 62 ff. (Ch. 28-29).

Iог. De normanniske hertugers bedrifter, To normanniske krøniker ([ed.] Albrechtsen): 35 f. (Ch. I I).

I02. Althoff 2004: I36 f.

I03. See Part I. 
